\title{
SUDSKI POSTUPAK PROTIV DR. IVANA PROTULIPCA PREDSJEDNIKA KRIŽARSKE ORGANIZACIJE PRED OKRUŽNIM SUDOM U ZAGREBU 15. LIPNJA 1938. GODINE
}

\author{
Zdravko MATIĆ \\ Damir STRUČIĆ \\ Hrvatsko vojno učilište „Dr. Franjo Tuđman“ \\ Zagreb, Hrvatska
}

\author{
UDK: 347.93 “1938“: 329.3 \\ DOI: $10.21857 /$ yl4okflwz9 \\ Prethodno priopćenje \\ Prihvaćeno: 28. kolovoza 2019.
}

Autori su na temelju arhivske građe i recentne literature istražili i analizirali suđenje koje je provedeno u postupku protiv dr. Ivana Protulipca, odvjetnika iz Zagreba i predsjednika Križarske organizacije, pred Okružnim sudom u Zagrebu, nadnevka 15. lipnja 1938. godine zbog krivičnog djela iz čl. 3. Zakona o zaštiti države Kraljevine Jugoslavije, kojim je državni tužitelj dr. Benjamin Maurović tražio za njega kaznu zatvora do pet godina. Suđenje je pokazalo da je bilo posve neosnovano te je oslobođen svake optužbe.

Ključne riječi: dr. Ivan Protulipac, Okružni sud, rasprava, Križarska organizacija, suđenje, presuda.

\section{POLITIČKA I DRUŠTVENA SITUACIJA U KRALJEVINI JUGOSLAVIJI}

Pokušaj ujedinjenja Hrvata i hrvatskih Srba i formiranje Seljačko-demokratske koalicije 1927. godine bio je dovoljan povod da Beograd shvati kako su Hrvati radili protiv njih, zbog čega će godinu dana kasnije doći do erupcije nezadovoljstva u Beogradskoj narodnoj skupštini. Ubojstva Đure Basaričeka, Pavla Radića, Ivana Granđe, Ivana Pernara i Stjepana Radića bili su snažan povod za iskazivanje nezadovoljstva hrvatskog naroda. Nakon atentata više ništa nije bilo isto. Oprez i strahovlada bili su dva antipoda koji su imali obilježje neizvjesnosti i tjeskobe i za Hrvate za i Srbe. Već 6. siječnja 1929. godine Aleksandar Karađorđević putem Radio Beograda objavio je ukidanje Narodne skupštine te svih političkih stranaka, kojim je činom uveo Šestosiječanjsku diktaturu. ${ }^{1}$ Od 1929. godine Kraljevina Jugoslavija bila je podijeljena u devet banovina. Granice su namjerno bile drukčije od etničkih granica. Glavni grad Savske Banovine bio je Zagreb, a Beograd je postao glavni grad Kraljevine Jugoslavije, ali nije pripadao ni jednoj banovini.

Međutim, dio hrvatskih političara, među kojima je bio dr. Vladko Maček, smatrali su to boljim rješenjem od Vidovdanskog ustava, ali i novom inicijativom za normalizaciju odnosa. Istovremeno, službeni Beograd pokušao je eliminirati 
političke protivnike koje je opet prepoznao među hrvatskim, ali i makedonskim, albanskim i slovenskim pripadnicima naroda kada je ubijen Josip Predavec, HSS-ov zastupnik, odmah nakon izlaska iz zatvora, zatim Đuro Đaković, jedan od visokopozicioniranih dužnosnika još uvijek tada ilegalne KPJ, albanolog i pisac, te pravaš Milan Šufflay, koji je ubijen usred Zagreba. ${ }^{2}$

Osim pojedinačnih atentata koje je revno provodio Beogradski režim, uslijedili su obračuni is većim skupinama kao što su Sibinjske, Senjske i Vrbske žrtve. ${ }^{3} \mathrm{~K}$ tomu, režimske vlasti nastojale su gospodarski i ekonomski iscrpiti Hrvatsku. Nova agrarna reforma ponovo je išla na ruku srpskom seljaštvu, tako su zemlja koja se dijelila prvo dobivali sudionici srpskih ustanaka, pa ratni veterani, a tek onda ostali. ${ }^{4}$

Sve navedeno probudilo je želju za osvetom. Brojni pokušaji atentata na kralja Aleksandra Karađorđevića nisu uspjeli. Poznato je da su ustaše već prethodno izveli dva pokušaja ubojstva kralja Aleksandra Karađorđevića. S obzirom na to da je kralj Karađorđević imao vrlo slabo osiguranje i nedostatak oružane zaštite, Paveliću su njegove organizacijske sposobnosti pomogle da podmiti visoke dužnosnike u kraljevu francuskom osiguranju. Ipak, za vrijeme posjeta Marseillu i vožnje ulicama, Vlado Černozemski, pripadnik VMRO-a, ubio je kralja iz neposredne blizine, a tijekom pucnjave poginuo je i ministar Barthou. Marseillski atentat od 9. listopada 1934. okončao je Aleksandrovu vladavinu, a velik teret osvete pao je na ustaše. Naime, ubrzo je otkrivena upletenost ustaša u planirani atentat, tako da su brojni ustaški kampovi po svijetu pozatvarani, a čelnici uhićeni. Čelnik marseillske policije Jouhannaud nakon atentata razriješen je dužnosti, a čelnik ustaša Ante Pavelić bio je uhićen 17. listopada 1934. u Italiji te je u zatvoru u Torinu bio do 12. srpnja 1936. godine kada je oslobođen. 5

Kada je regentom imenovan Pavle Karađorđević, on je odmah uspostavio tročlano Namjesništvo koje je znatno bolje obavljalo dužnost, ali time se nisu

2 Ubojstvo Milana Šufflaya snažno je odjeknulo u svijetu, posebice zbog naknadnog zataškavanja od vlasti (o tome se, naime, nije pisalo ni govorilo), a na ponašanje beogradske vlasti pismom su reagirali, između ostalih, i Albert Einstein i Heinrich Mann. Mladen Švab, Milan pl. Šufflay, 120. godišnjica rođenja. Djelo dostojno pozornosti, Vijenac, br. 149/1999., 74; H. Mat ković, Povijest Jugoslavije, 174.

3 Mato Artuković, Nadbiskup Stepinac o sibinjskim žrtvama i mise zadušnice za njih u crkvama Zagrebačke nadbiskupije u veljači i ožujku 1935. godine, Diakovensia, 26., 2018., 583 - 607.

4 Odnos hrvatskih i srpskih časnika i državnih službenika raspoređenih na važnim državnim funkcijama je bio neravnomjeran. Tako je primjerice od ukupnog broja generala broj srpskih generala bio 161, dok je broj hrvatskih generala bio 2. Slični omjeri bili su i na drugim funkcijama. H. Mat ković, Povijest Jugoslavije, 140 - 143.

5 U zatvoru je Pavelić napisao roman Lijepa plavojka. Mario JAREB, Ustaško-domobranski pokret: od nastanka do travnja 1941. godine, 2. izd., Zagreb, 2007., 321 - 322. 
ni blizu nazirala konačna rješenja stanja u Jugoslaviji. Jedno od pitanja koje su razriješili bila je Konkordatska kriza. Pregovori oko stvaranja Sporazuma između Kraljevine Jugoslavije i Vatikana trajali su duže vrijeme, a dokument je konačno potpisan 1935., u vrijeme nadbiskupa Antuna Bauera. ${ }^{6}$ Međutim, odmah potom uslijedili su snažni prosvjedi i reakcija pravoslavnih svećenika, koji su ustvrdili kako se Hrvatima time daje prevelika autonomija, što je rezultiralo time da konkordat nikada nije ratificiran. ${ }^{7}$

U nizu pitanja koja su ostala neriješena između beogradskog režima i Katoličke crkve, koja je bila dodatno izložena napadima i od strane Srpske pravoslavne crkve, na udaru su se našle brojne katoličke organizacije. Jedna od najbrojnijih katoličkih organizacija koja je djelovala u Hrvatskoj od 1930. do 1945. bila je Križarska organizacija koja je osnovana netom nakon zabrane rada Hrvatskog orlovskog saveza. Početkom 1932. i 1933. godine pojačao se sukob Katoličke crkve i režimskih vlasti koji je bio izražen između ostalih i kroz nametanje sokolske ideologije katoličkoj mladeži. ${ }^{8}$ To je rezultiralo još snažnijim otporom i dodatnim naporima članova koji su masovno napuštali sokolske organizacije. Kao potpora katoličkoj mladeži uslijedila je reakcija Hrvatske bogoslovske akademije koja je 9. ožujka 1932. žestoko napala „bezbožnu ideologiju Čeha dr. Miroslava Tyrša“, na kojoj je zapravo počivala cjelokupna Sokolska organizacija. ${ }^{9}$

Cijela 1933. bila je u znaku Katoličke crkve koja je bila u fokusu svih zbivanja. U prigodi novogodišnjih čestitanja papa Pio XI. upozorio je savjetnika beogradske Vlade Nikolu Moscatella (poslanik Jevrem Simić bio je na savjetovanju u Beogradu) da se u Jugoslaviji događaju brojne stvari koje vlasti ne kontroliraju. ${ }^{10}$

6 Peter Sugar, Native fascism in the Successor States, 1918-1945. Issue 4 of Twentieth century series. ABC-Clio, 1971., 139; M. JAREB, Ustaško-domobranski pokret: od nastanka do travnja 1941. godine, 185 .

7 Jedno od važnih pitanja koje su Hrvati nametali odnosilo se na politički status Hrvatske. Naime, nakon smjene Bogoljuba Jevtića 1935. godine za premijera je postavljen Milan Stojadinović, vođa Jugoslavenske radikalne zajednice koji je započeo pregovore s Vladkom Mačekom oko statusa Hrvatske iako za njegova mandata (1935. - 1939.) to pitanje neće biti do kraja riješeno. Godine 1939. knez Pavle smjenjuje Milana Stojadinovića i imenuje Dragišu Cvetkovića za novog predsjednika vlade. Kako su pregovori Stojadinović-Maček bili neuspješni, novi predsjednik vlade započinje nove pregovore koji su 26. kolovoza 1939. godine rezultirali potpisivanjem Sporazuma Cvetković-Maček i osnivanjem Banovine Hrvatske.

8 Ivan ĆuBelić, Biskupske konferencije Jugoslavije i Hrvatski katolički pokret (1919. - 1945.), Zagreb, 1997., 532.

9 I. ĆUBELIĆ, Biskupske konferencije Jugoslavije, 532.

10 Nikola Moscatello (Dol, 7. lipnja 1885. - Rim, 13. srpnja 1961.) bio je hrvatski svećenik i hrvatski diplomat. Bio je savjetnik jugoslavenskog poslanstva pri Svetoj stolici i otpravnik poslova socijalističke Jugoslavije pri Svetoj stolici. Govorio je šest stranih jezika. Fabijan VERAJA, Nikola Moscatello: savjetnik jugoslavenskog poslanstva pri svetoj stolici: "Uspomene" u svjetlu dokumenata: doprinos povijesti katolicizma u Jugoslaviji: (1922.-1946.), Rim-Split, 2014., 425. 
Moscatellov pokušaj da objasni situaciju Papa je prekinuo s upozorenjem da Katoličku crkvu ne zanima politika, nego samo interesi katolika, a položaj katolika u Jugoslaviji bio je vrlo nepovoljan. ${ }^{11}$ Nakon što se vratio u Beograd, poslanik Simić razgovarao je s kardinalom Pacellijem kojemu je vrlo direktno rekao da su za zategnute odnose između Crkve i države odgovorni katolički biskupi. Narodnog poslanika Jevrema Simića je 3. veljače 1933. primio osobno papa Pio XI., o čemu je isti izvijestio svoju Vladu. ${ }^{12}$ U dopisu Simića Vladi u Beogradu između ostaloga se ističe kako je biskupska Poslanica od 17. studenog 1932. izazvala „uzbuđenje i negodovanje te komešanje naroda, uključujući i katolički“. Kardinal državni tajnik Pacelli informirao se kod Simića o namjeri Vlade prema kojoj je kanila zabraniti rad isusovaca u Kraljevini Jugoslaviji, na što $\mathrm{mu}$ je Simić odgovorio da je riječ o zlobnom podmetanju. ${ }^{13}$

Godine 1934. Alojzije Stepinac izabran je za nadbiskupa koadjutora s pravom nasljedstva u Zagrebačkoj nadbiskupiji. Bilo je to u vrijeme kada je došlo do novih sukoba i nerazumijevanja beogradskog režima, napose nakon atentata na kralja A. Karađorđevića u Marsellieu u listopadu 1934. godine. Upravo je u listopadu nadbiskup koadjutor Alojzije Stepinac proveo anketu među katoličkim intelektualcima s pitanjem o katoličkim organizacijama (jučer-danas-sutra). Petar Grgec, ugledni član Hrvatskog katoličkog pokreta i Seniorata, istaknuo je da je za sve odgovoran Episkopat koji nikada nije pokazao ozbiljnu namjeru da upravlja i vodi katoličke organizacije. ${ }^{14}$

Početkom 1936. zagrebački nadbiskup koadjutor Alojzije Stepinac objavio je Poslanicu kojom je definirano djelovanje katoličkih organizacija pa je stoga već 5. veljače 1936. osnovano Dijecezantsko vijeće Katoličke akcije. Za predsjednika vijeća Katoličke akcije Stepinac je imenovao dr. Ivana Protulipca, predsjednika Križara, kojega je smatrao čovjekom velikog ugleda i koji je uživao autoritet o kod jedne i kod druge strane. Međutim, neki su primijetili da izbor dr. Protulipca nije bilo najbolje rješenje jer je njegov izbor naišao na žestok otpor Domagojaca. ${ }^{15}$ Da bi smirio strasti, nadbiskup A. Stepinac 26. veljače 1936. izdao je Okružnicu prema kojoj je ujedinio sva društva muževa i žena, ali nije ukinuo nazivlja društava. $U$ jednom trenutku shvatio je kako još nije vrijeme da laici preuzmu

11 Jure KRIŠTo, Hrvatski katolički pokret 1903.-1945., Zagreb, 2004., 200 - 201.

12 Milan Bulajıć, Misija Vatikana, Beograd, 2004., 207 - 209.

13 Nikola Žutić, Kraljevina Jugoslavija i Vatikan, Beograd, 1944., 410; J. KRIšTo, Hrvatski katolički pokret 1903.-1945., 201.

14 I. ĆuBELIĆ, Biskupske konferencije Jugoslavije, 534.

15 B. Zelić-BuĆAn, Djelovanje domagojskih organizacija 30-tih godina XX. stoljeća, Marulić, 26./1993., br. 4., 588. 
vođenje Katoličke akcije, pa je Stepinac zamolio Protulipca da podnese ostavku te se osobno postavio na njezino čelo. ${ }^{16}$

Početkom 1937. godine crkveni krugovi ipak su najviše strepili od širenja komunizma. O tome piše i istaknuti član Domagojevaca Ivo Lendić u svojim memoarima, ali i drugi katolički uglednici. Bila su to i osobna Stepinčeva razmišljanja. Stoga je papa Pio XI. 19. ožujka 1937. donio encikliku Divini Redemptoris kojom je obznanio okružnicu protiv komunizma. ${ }^{17}$ I katolički je episkopat 1937. objavio poslanicu o socijalnom pitanju kojom osuđuje gospodarski liberalizam i komunizam. ${ }^{18}$

U nizu organizacija koje su djelovale u Savskoj Banovini bila je i Križarska organizacija koju je predvodio dr. Ivan Protulipac. Rad Križarske organizacije nailazio je na niz poteškoća od strane aktualne vlasti. Policija je povećala nadzor nad svim križarskim okružjima. ${ }^{19}$ Započela su i privođenja, vršeni su pretresi službenih prostorija križarskih organizacija te su kažnjavani zbog posjedovanja službenih materijala, plakata, znački ili zastava VKB-a. ${ }^{20}$ Unatoč pritiscima vlasti, Križarske organizacije pronašle su put za svoje djelovanje. Tako prema Zapisniku 37. sjednice Velikog Križarskog Bratstva održane 27. rujna 1937. Križarska je organizacija radila na omasovljenju društva. ${ }^{21}$

Na sjednici VKB-a održanoj 6. listopada 1937. njezin predsjednik dr. Ivan Protulipac predložio je nova tijela u strukturi unutarnjeg poslovanja VKB-a. Tako su ustrojene službe referenta za tisak i za propagandu. ${ }^{22}$ Iako je bilo očigledno da je potrebno provesti reforme koje su uključivale podređenost svih katoličkih

16 Predgovor za Stepinčev dnevnik napisao je akademik Ljubo Boban, koji je dnevnik Alojzija Stepinca nazvao nepoznatim dnevnikom. Objavljen je u nastavcima u tjedniku Danas od 25. srpnja 1989. do 30. siječnja 1990. Neki smatraju da dnevnik nije autentičan. Ljubo BoBAN, Alojzije Stepinac: Nepoznati dnevnik (dalje: Stepinčev Dnevnik), Danas, Zagreb, 25. srpnja 1989. - 30. siječnja 1990., 21. studenog 1989., 65.

17 Encikličko pismo pape Pija XI. „Divini Redemptoris“, o bezbožnom komunizmu, Katolički list, 88. 1937., br. 14.

18 Socijalna poslanica Katoličkog Episkopata, Luč, br. 3-4., 1937., 4 - 6.

19 HR-HDA, Fond: Kraljevska banska uprava Savske banovine, Otsek za državnu zaštitu, Pov. II. D. Z. broj 8509-1935, Zagreb, 22. februara 1935.

20 HR-AHBK, Posebni fascikl, „Katolička Akcija - Orlovi - Križari“, 36, Žalba Ministarstvu unutarnjih poslova u Beogradu zbog progona Križara.

21 HR-Arhiv dr. Lava Znidarčića, (dalje: ALZ) Fond: Križarstvo, Zapisnici Velikog Križarskog Bratstva 1930-1945. Sjednici su nazočili dr. Ivan Protulipac, dr. Avelin Ćepulić, S. Šarić, S. Ramljak, Stiperski, Malinar, I. Tubaković i Frane Grgić kao izvjestitelj. Razvidno je da su Križarske organizacije bile prisutne u Novskoj, Novoj Gradiški, Lipovljanima, Vrbju, Novoj Gradiški, Davoru i Orubici - Staro Petrovo Selo.

22 HR-ALZ, fond: Križarstvo, kut. 3., Zapisnik sjednice Velikog križarskog bratstva od 6. listopada 1937. godine. 
organizacija pod kapu Katoličke akcije, nadbiskup Stepinac u svome Dnevniku tvrdi da je došlo do smirivanja među katoličkim organizacijama. ${ }^{23}$

\section{ŽIVOTOPIS DR. IVANA PROTULIPCA, PRVOG PREDSJEDNIKA KRIŽARSKE ORGANIZACIJE}

Dr. Ivan Protulipac rođen je u Hrnetiću (Karlovac) 4. srpnja 1899. godine, od oca Janka i majke Dore (r. Bezjak), kao prvo dijete obitelji od devetero djece. Pučku školu pohađao je u Hrnetiću od 1906. do 1910. godine. Iste je godine upisao gimnaziju u Karlovcu, gdje je maturirao 2. srpnja 1918. godine. Kao odličan učenik upisao je 1918. Pravni fakultet Sveučilišta u Zagrebu na kojemu je diplomirao 1923. godine, a promoviran je u čast doktora prava 31. listopada 1923. na prijedlog rektora dr. Stjepana Zimmermanna, dekana dr. Ernesta Milera i promotora dr. Ede Lovrića. ${ }^{24}$

Nakon studija bio je u razdoblju od 24. travnja 1923. do 2. studenog 1927. godine odvjetnički pripravnik kod dr. Ćirila Brajše u Karlovcu, dr. Vladimira i Veljka Prebega u Zagrebu, dr. Dražena Kvaternika u Bjelovaru i dr. Aleksandra Horvata u Zagrebu.

Od 2. studenog 1927. bio je samostalan odvjetnik u Zagrebu, u Vlaškoj ulici br. 2, a dolaskom komunista i po nalogu „delegata“ u Odvjetničkoj komori u Zagrebu brisan je iz popisa odvjetnika s datumom 19. studenog 1945. godine, rješenjem Komesara Odvjetničke komore od 6. travnja 1946. ${ }^{25}$

Već kao student prava 1920. godine prisustvovao je Orlovskom sletu u Mariboru, gdje je pozvao prisutne Hrvate da stupe u orlovske redove. Na osnivačkoj skupštini Hrvatskog orlovskog saveza (HOS-a) u Zagrebu 16. prosinca 1923. izabran je za prvog predsjednika HOS-a, a dr. Ivan Merz za tajnika HOS-a. ${ }^{26} \mathrm{Na}$ tom je položaju ostao do raspuštanja Orlovske organizacije u prosincu 1929. godine. ${ }^{27}$

23 Napominjem da sam kod citiranja Dnevnika Alojzija Stepinca, koristio prijepis njegova Dnevnika koji je objavljen u tjedniku Danas, 1990. godine, u nastavcima, s obzirom da mi originalni Dnevnik nije bio dostupan. Dnevnik A. Stepinca, u: Danas, 29. lipnja 1990., 64.

24 HR-Arhiv Ivana Merza (dalje: HR-AIM), Zagreb; Spomenica, Dr. Ivan Protulipac 1899.-1946., Zagreb, 1996., 5.

25 HR-Hrvatski državni arhiv (dalje: HR-HDA), fond SB DZ 24868/1931., Uprava policije u Zagrebu, Pretsednički Ured: Dr. Ivan Protulipac - podaci od 3. 12. 1931. godine.

26 HR-Arhiv hrvatske biskupske konferencije (dalje: HR-AHBK), Pismo s prilogom dr. Ivana Protulipca, predsjednika HOS-a preuzvišenom gosp. dr. Antunu Baueru, zagrebačkom nadbiskupu, od 28. XII. 1923.

27 HR-HDA, fond SB DZ 24868/1931.; Arhiv dr. Lava Znidarčića, (Dalje: HR-ALZ), kut. 3. „Križarska organizacija“. 
U dopisu što ga je 28. prosinca 1923. poslao zajedno s dr. Ivanom Merzom zagrebačkom nadbiskupu dr. Antunu Baueru, obavještava ga da je došlo do reorganizacije Hrvatskog katoličkog omladinskog saveza, kojemu je na čelu bio dr. Ivan Merz. U dopisu se ističe da je donesena odluka nakon održane konstituirajuće glavne skupštine Hrvatskog orlovskog saveza od 16. prosinca 1923., na kojoj je izabrano vodstvo nove organizacije. ${ }^{28}$

Nakon zabrane rada Hrvatskog orlovskog saveza, u suradnji s kanonikom mons. Milanom Beluhanom, isusovcima Brunom Foretićem i Josipom Vrbanekom, dr. Avelinom Ćepulićem, Maricom Stanković i drugima godine 1930. osniva Križarsku organizaciju kojom postaje predsjednikom, ali na osnivačkom vijeću održanom 6. travnja 1930. godine izabran je za predsjednika Velikog križarskog bratstva, što je bilo središnje vodstvo Križarske organizacije. ${ }^{29}$

Međutim, već prvih dana Križarstva bio je uhićen 27. siječnja 1930. pod inkriminacijom da je „kao predsednik Orlovskog Saveza potajno organizirao organizaciju „Križari“ iz članova bivših Orlova, kojima je 6. 01. 1929. bilo djelovanje kao vjersko-političkoj organizaciji zabranjeno. Radi ovog bio je predan 5. 02. 1930. u ured Sudbenog stola u Zagrebu s prijavom na državno odvjetništvo [...] $]^{\text {“30 }} \mathrm{U}$ istražnom zatvoru u Zagrebu proveo je mjesec dana, što je kasnije opisao u svom prikazu „Iz prvih dana Križarstva“. ${ }^{31}$ Kad ga je njegov otac došao posjetiti 1930. god. u zloglasnom zatvoru Glavnjača, Ivan mu je rekao riječi koje su imale proročanski prizvuk: „Ja sam svoj put zacrtao i znam zašto. Bez obzira što se dogodilo neka nitko za mnom ne plače. Bog živi!“32

Koliko je dr. Protulipcu bila važna nova organizacija najbolje svjedoči njegov članak pod naslovom „U znaku križa“ što ga je objavio u siječnju 1930. g. u prvom broju lista Križ, glasila tek osnovane Križarske organizacije. „Naš narod danas željno čeka da dođe omladina koja će poput križara Božjih ponijeti novi duh po našim krajevima [...]. Program je te omladine jasno vidljiv u Kristovu križu [...]. A poteškoće, mi ih vidimo. Ali, iza Velikog Petka dolazi Uskrs. Do njega mora doći [...]. Mi hoćemo i Veliki Petak da dođe tim sjajniji Uskrs. Da li si nas razumjela hrvatska omladino i vi hrvatski katolici? "33

28 HR-AHBK, dr. Ivana Protulipca, predsjednika i Jerolima Malinara, tajnika HOS-a, preuzvišenom gosp. dr. Antunu Baueru, zagrebačkom nadbiskupu, od 28. XII. 1923.

29 HR-ALZ, kut. 3. „Križarska organizacija“.

30 HR-HDA, fond SB DZ Pov. br. 24868/1931., „Uprava policije u Zagrebu, Pretsednički ured, Kr. Banskoj Upravi Savske Banovine, Odeljak državne zaštite, Dr. Ivan Protulipac - podaci od 3. XII. 1931. godine; HR-Državni arhiv Zagreb (Dalje: HR-DAZ) Kzp. 606-30., Prijava državnog odvjetništva Zagreb.

31 Ivan Protulipac, Iz prvih dana Križarstva, Nedjelja, br. 77., 1936., 7.

32 I. Protulipac, Iz prvih dana Križarstva, 7.

33 Ivan Protulipac, U znaku križa, Križ, br. 1., 1930. 
Bio je to zapravo programatski članak koji je dr. Protulipac namijenio novoosnovanoj Križarskoj organizaciji. O radu dr. Ivana Protulipca u Križarskoj organizaciji najbolje svjedoče riječi o. Bonifacija Perovića koji piše o njemu ovako: „Hrvatski orlovski, kasniji križarski pokret ne daju se zamisliti u svojoj povijesnoj perspektivi bez osobe Protulipca [...]. Bio je pošten čovjek, moralnog ponašanja bez prigovora, dobar vjernik, požrtvovan do neumrlosti i trajno siromašan. Bio je čovjek pun zanosa, ali ne fanatik; nije bio dvoličan premda se znao poslužiti vještom strategijom. Bio je snažan govornik i velik organizator. Može se o njemu slobodno reći da je žrtvovao sebe, svoje vrijeme i snage za orlovski i križarski pokret kojima je stajao na čelu. Bio je stvaran, točno je znao što hoće i to je provodio željeznom voljom i žrtvom [...].“34 Međutim, policija je ponovno protiv njega pokrenula kaznenu prijavu. Optužen je ponovno po Zakonu o zaštiti države pred Okružnim sudom pod brojem Kps 427/31, ali je nakon provedenog postupka bio oslobođen svake krivnje jer Sud nije našao ništa $\mathrm{u}$ tome članku što bi bilo protiv Zakona. ${ }^{35}$

$\mathrm{Na}$ izbornoj skupštini izabran je za predsjednika Katoličke akcije za Zagrebačku nadbiskupiju u siječnju 1936., ali je već u ožujku iste godine podnio ostavku. Bio je također aktivan od 1939. godine do lipnja 1941. u radu „Saveza hrvatskih junaka" gdje je obnašao dužnost saveznog vođe. Dužnost predsjednika Velikog križarskog bratstva prestao je obavljati u prosincu 1938. godine. ${ }^{36}$

Protulipac se vjenčao se s Nadom Klemenčić 1. kolovoza 1943. U kratkom braku nije imao djece. Njegova supruga dočekala je povratak njegovih posmrtnih ostataka u domovinu 1993. godine.

Zbog bojazni od odmazde komunističkih vlasti, dr. Ivan Protulipac napustio je Zagreb 6. svibnja 1945., kao i brojni Hrvati koji su potražili sigurnije utočište pred naletom komunističkih progonitelja. Kraće vrijeme boravio je u Austriji (Klagenfurt), a zatim kratko odlazi u Italiju (Rim i Trst) s ciljem da pomaže izbjeglicama iz Hrvatske. Već je bio došao do Rima i bio je na sigurnom, međutim zbog vijesti o mnogobrojnim hrvatskim izbjeglicama koji su hrlili prema granici tražeći spas pred partizanskim egzekutorima, dr. Protulipac vratio se natrag u Trst s jedinom namjerom da pomogne svojim sunarodnjacima koji su tražili utočište i spas u Italiji i drugim europskim zemljama. Prema pričanju vlč. Stanislava Golika, namjeravao je čak osnovati jedno transportno poduzeće od čije bi dobiti pomagao našim ljudima. U Trstu je zajedno s vlč. Stanislavom Golikom pomagao izbjeglicama, brinuo se revno za njih, tražio smještaj, nabavljao im

\footnotetext{
34 Bonifacije Perović, Hrvatski katolički pokret, Rim, 1976., 112.

35 HR-DAZ, Kps 427/31, Okružni sud u Zagrebu, Sudska presuda od 14. 02. 1931.

36 Spomenica, Dr. Ivan Protulipac 1899.-1946., Zagreb, 1996., 5.
} 
hranu, držao vjeronauk te pomagao organizirati svete mise. Vlč. Stanislav Golik, hrvatski svećenik koji se kasnije preselio u Ameriku, sjeća se dobro kako mu je dr. Protulipac pomagao kod organiziranja svetih misa i vjeronauka. Vlč. Golik pobrinuo se za tijelo dr. Protulipca kada je bezočno ubijen u atentatu i osigurao mu je grob u kojem je počivao sve do prijenosa u Domovinu. ${ }^{37}$

Odvjetnik dr. Ivan Protulipac ubijen je u Trstu 31. siječnja 1946. godine na ulici usred bijela dana iz revolvera s prigušivačem. Bio je službeno prva žrtva tajne jugoslavenske policije UDBE. Ubio ga je usred bijela dana agent UDBE jugoslavenskih komunističkih vlasti pod pseudonimom Gino Benčić. ${ }^{38}$ Imajući sve to u vidu, očito je da je dr. Ivan Protulipac poginuo kao žrtva ljubavi za svoj hrvatski narod, kojemu je već i prije posvetio sav svoj život radeći za njegovu vjersku i moralnu obnovu u Orlovsko-križarskoj organizaciji. ${ }^{39}$

O uhićenju ubojice i njegovu zločinu izvijestile su odmah sutradan i narednih dana tri tršćanska glasila (La Voce libera, Il Corriere di Trieste i Giornale Alleato) iz kojih doznajemo ime ubojice, da je bio 21 god. star i rodom bio sa Sušaka, kako mu je pisalo u dokumentu koji je kod njega nađen. Kod ubojice je bila pronađena i lista osoba koje je trebalo likvidirati. Na prvom mjestu bio je dr. Ivan Protulipac. Za vrijeme saslušanja ubojica je padao u razne kontradikcije. List $L a$ Voce libera od 6. veljače 1946. u članku posvećenom istrazi o ubojstvu tvrdi da je „opće mišljenje da je zločin organizirala OZNA koja je zadužila Benčića da ubije opasnog političkog protivnika“. ${ }^{40}$

Poznato je da su tadašnje jugoslavenske vlasti i njihove tajne službe vršile pojedinačne egzekucije tzv. vanjskih neprijatelja koji su se na bilo koji način ogriješili o režim. Da je zločin u tom smislu stvarno bio organiziran, potvrđuje i sljedeća činjenica koju donosi dr. Krunoslav Draganović: „[...] istodobno su jugoslavenske vlasti s druge strane granice uhitile dvojicu engleskih oficira. Kako je ubojica bio uhvaćen i predan engleskim vojnim vlastima koje su tada kontrolirale Trst, predložena je zamjena i ubojica dr. Protulipca, Gino Benčić vratio se onima koji su ga poslali.“41

37 Božidar Nagy, Dr. Ivan Protulipac u Domovini. Prijenos posmrtnih ostataka dr. Protulipca iz Trsta u Zagreb, u: Ivan Merz, Glasilo Postulature, br. 1-2 (17), Zagreb, 1994., 25 - 28.

38 Prema dokumentima koje je talijanska policija pronašla kod ubojice, isti se zvao Gino Benčić, star 21 godinu, rođen u Sušaku. Njegova osobna karta nosila je datum izdavanja 17. siječnja 1945. Podatci o ubojici objavljeni su u talijanskim novinama La Voce libera, Il Corriere di Trieste i Giornale Alleato.

39 B. Nagy, Dr. Ivan Protulipac u Domovini, 23.

$40 \quad$ La Voce libera od 6. veljače 1946. 2; B. NAgY, Dr. Ivan Protulipac u Domovini, 2.

41 B. NAgy, Dr. Ivan Protulipac u Domovini, 25 - 28. 
U privatnom arhivu dr. Lava Znidarčića u fondu Križarske organizacije, $u$ omotu spisa kutije, nalazi se papirić napisan rukom: Ivan Škerl, pravo ime ubojice $d r$. Ivana Protulipca. Očigledno da je već dugo poznato ime ubojice dr. Protulipca, ali, kao i u velikoj većini slučajeva, ubojica nije procesuiran. ${ }^{42}$

Dugo poslije rata bilo je zabranjeno govoriti o članovima Križarske organizacije te pisati i spominjati njihova imena. Radi ilustracije, o dr. Ivanu Protulipcu također je bilo zabranjeno pisati jer je poslije njegova ubojstva bilo nedvojbeno da ga je uklonio jugoslavenski komunistički režim. Svako spominjanje njegova imena u javnosti povlačilo je za sobom sankcije režima. Tako je na primjer Hrvatsko književno društvo sv. Ćirila i Metoda u Zagrebu 1972. g. objavilo u kalendaru Danici njegovu kratku biografiju zajedno s biografijom Marice Stanković. ${ }^{43}$ Komunističke vlasti zaplijenile su Danicu. Ili drugi slučaj: početkom 1986. godine Glas Koncila objavio je mali oglas - poziv na molitvu za dr. Ivana Protulipca prigodom 40. obljetnice njegove smrti. Nakon nekoliko dana uslijedio je oštar članak u zagrebačkom Vjesniku pod naslovom „Križarski poziv iz groba“ pun neutemeljenih napada protiv dr. Protulipca i Križarstva, lažno ih povezujući $s$ fašističkom ideologijom itd. Očito je bilo koliko se komunistički režim još uvijek bojao Križarstva i njegovih velikana, odnosno koliko su oni bili vrijedni s obzirom na to da je režim nastojao ušutkati svaki njihov spomen u javnosti. ${ }^{44}$

Tijelo dr. Ivana Protulipca prevezeno je 25. lipnja 1993. godine iz Trsta u Domovinu i uz sve počasti koje dolikuju hrvatskom katoličkom velikanu i mučeniku, sahranjeno sutradan, 26. lipnja u Zagrebu na Mirogoju. ${ }^{45}$ Cijelu akciju prijenosa tijela organizirala je tek obnovljena Križarska organizacija kojoj je to bio jedan od prvih velikih pothvata nakon nastavka javnog djelovanja. Dr. Ivan Protulipac prvi je hrvatski mučenik koji je ubijen u emigraciji i prvi čije se tijelo vratilo u Domovinu. Po dolasku u Zagreb, posmrtni ostatci najprije su dovezeni u baziliku Srca Isusova, gdje su mu najbliža rodbina, prijatelji i znanci iskazali prvu počast. Nakon sv. mise, koju je predvodio o. Božidar Nagy, pokojnika je pozdravio njegov treći nasljednik u vodstvu organizacije, dr. Lav Znidarčić, predsjednik Velikog križarskog bratstva. Ovim činom prijema u bazilici Srca Isusova, u koju je dr. Protulipac često dolazio, osim prvog pozdrava, željelo se također na simboličan način upriličiti susret dr. Protulipca s njegovim prijateljem

42 HR-ALZ, kut. 3. „Križarska organizacija“.

43 B. Nagy, Dr. Ivan Protulipac u Domovini, 25 - 28.

44 B. Nagy, Dr. Ivan Protulipac u Domovini, 37.

45 Organizaciju prijenosa posmrtnih ostataka i pogreb vodilo je obnovljeno Križarsko bratstvo intelektualaca. Nakon sv. mise lijes s posmrtnim ostatcima dr. Protulipca prekriven križarskom zastavom iznijeli su predsjednik VKB dr. Lav Znidarčić te braća Križari, suradnici u Vodstvu križarske organizacije: dr. Fedor Cicak, gosp. Nemet i prof. Frano Barišić. 
i suradnikom dr. Ivanom Merzom koji počiva u toj bazilici, a na čije je mjesto na Mirogoju tijelo dr. Protulipca od tada položeno da počiva u hrvatskoj grudi. ${ }^{46}$

Svečana sahrana na Mirogoju. - Na svečani ispraćaj dr. Ivana Protulipca na njegovo vječno počivalište na Mirogoju došla je njegova supruga, dva brata i dvije sestre i ostala rodbina, njegovi prijatelji i suradnici, križari i križarice iz Zagreba i izvan Zagreba te brojni vjernici. ${ }^{47} \mathrm{Na}$ pogreb su došli njegovi prijatelji križari čak iz Sjeverne Amerike, Južne Amerike i Australije. Pogrebnu sv. misu u crkvi Krista Kralja na Mirogoju predvodio je zagrebački pomoćni biskup mons. Marko Culej u koncelebraciji s petnaestak svećenika. Bili su nazočni i izaslanici šibenskog i đakovačkog biskupa te predstavnici redovničkih zajednica: isusovaca, franjevaca konventualaca i kapucina. Donesene su bile orlovske i križarske zastave, čuvane i sakrivane godinama kod križara ili po župnim dvorovima. Kod sv. mise pjevao je zbor zagrebačke katedrale koji je kod groba otpjevao križarsku himnu. U svojoj propovijedi biskup Culej je rekao da dr. Protulipac, taj „velikan i mučenik hrvatskog naroda, nije među nama da bi umnožio grobove još jednom svježom rakom (takvih je i previše), već da bi pokazao kako se žrtvom i euharistijom sjedinjuju duša i Domovina" ${ }^{4} 8$

\section{SUĐENJE DR. IVANU PROTULIPCU 15. LIPNJA 1938. NA OKRUŽNOM SUDU U ZAGREBU}

Glavna rasprava protiv dr. Ivana Protulipca održana je 15. lipnja 1938. godine pred Okružnim sudom u Zagrebu, ${ }^{49}$ zbog navodno počinjenog kaznenog djela iz člana 3. Zakona o zaštiti države Kraljevine Jugoslavije koju je zastupao državni tužitelj dr. Benjamin Maurović, koji je tražio kaznu zatvora od pet godina. ${ }^{50}$ Rasprava je započela u 8 sati u velikoj dvorani Okružnog suda koju su ispunili članovi Križarske organizacije i brojni građani.

46 B. Nagy, Dr. Ivan Protulipac u Domovini, 37.

47 Kod groba su se od pokojnika oprostili u ime Velikog križarskog bratstva dr. L. Znidarčić, u ime Velikog križarskog sestrinstva Slavica Tuškan, postulator kauze za beatifikaciju Ivana Merza o. Božidar Nagy, predsjednik Odvjetničke komore koje je pokojnik bio član dr. Očić, dr. Fedor Cicak u ime braće Križara, vlč. Viktor Štimac, dekan Karlovačkog dekanata u ime rodne župe pokojnika, te Dario Sironić, predsjednik obnovljenog Bratstva intelektualaca križara.

48 Propovijed biskupa Marka Culeja, 26. lipnja 1993., http://krizari.hr/ivan-protulipac-prvipredsjednik-orlovstva-i-krizarstva-hrvatski-mucenik-1899-1946/, datum posjeta: 14. srpnja 2020.

49 HR-DAZ, fond Okružni sud u Zagrebu, Broj Kps. 3508-38, Presuda od 15. juna 1938., HR-ALZ, kut. 3. „Križarska organizacija“.

50 HR-DAZ, fond Okružni sud u Zagrebu, Broj Kps. 3508-38, Presuda od 15. juna 1938., HR-ALZ, kut. 3. „Križarska organizacija“. 
Državni tužitelj teretio je dr. Ivana Protulipca za kazneno djelo jer je 22. kolovoza 1937. za vrijeme Euharistijskog kongresa u Bosanskom Brodu, na jednom u nizu Križarskih zborovanja, na početku svojega govora kao predsjednik Velikog Križarskog bratstva navodno izrekao sljedeće riječi: „Mi Križari, kad smo došli u ovo mjesto na Euharistijski kongres, mnogi kad su nas vidjeli u našim uniformama, pitali su se, tko smo i šta hoćemo, a ja im kažem, da hoćemo samostalnu hrvatsku državu, koja nam se mora dati, a ako nam se neće dati, mi ćemo je silom oživjeti [...].“s1

U svome uvodnom govoru državni tužitelj Maurović istaknuo je da izrečene riječi prema optužnici čine krivično djelo po članu 3. Zakona o zaštiti države, te je tražio kaznu zatvora do pet godina. Nakon dovršenja dokaznog postupka stavio je i obrazložio svoj konačni prijedlog ostajući u cijelosti kod podignute optužnice. U obrazloženju svoga konačnog prijedloga tužitelj je između ostaloga rekao: „Ovakav pokret, kreće se na području duha i značaja, te je veoma važan po društvo. Križarstvu je glavna svrha odgoj omladine u duhu kršćanstva, a na temelju Evanđelja i nauke Kristove. Ovakvo Križarstvo kao bitne točke svojega izričito crkvenoga programa imade nepolitičnost i vanstranačnost. ${ }^{\text {"S2 } 2}$

Maurović je bio mišljenja da pokret „Križarstva“ zadnjih godina udaljio po nekim svojim predstavnicima od duhovnog područjai zašao na područje svjetovne politike, upozorivši sud na neke pojave unutar organiziranih katolika, a u vezi sa stavom nekih društvenih čimbenika, primjerice dnevnih novina. Upravo stoga je on smatrao da je opravdana sumnja izražena u optužnici, podignutoj na iskazima svjedoka optužbe, pa je zbog toga i ostao kod same optužnice i predložene kazne.

\section{ISKAZI SVJEDOKA}

Kao svjedoci saslušani su redom kao i u istrazi: Rajko Kušlić, Gojko Gajić, Savo Stjepanović, Ilija Čičić, Dedo Hadžiruflić, Tomislav Mesić, Vjekoslav Švajger i Milivoj Mostovac. ${ }^{53}$ Prema dokumentima sudskog procesa protiv dr. Ive Protulipca prvi je svjedočio Rajko Kušlić koji je u istrazi kazao da je optuženi držao govor te je govoreći o križarstvu rekao slijedeće: „Mene su pitali, kada su nas vidjeli u našim uniformama - što je to, a ja sam im rekao, mi hoćemo

51 HR-DAZ, fond Okružni sud u Zagrebu, Broj Kps. 3508-38, Presuda od 15. juna 1938.; HR-ALZ, kut. 3. „Križarska organizacija“.

52 HR-DAZ, fond Okružni sud u Zagrebu, Broj Kps. 3508-38, Presuda od 15. juna 1938.; Za istinu, izdavač dr. Vladimir Cicak, Zagreb, 1938.; HR-ALZ, kut. 3. „Križarska organizacija“.

53 HR-DAZ, fond Okružni sud u Zagrebu, Broj Kps. 3508-38, Presuda od 15. juna 1938.; HR-ALZ, kut. 3. „Križarska organizacija“. 
samostalnu hrvatsku državu, koja nam se neće dati mi ćemo je silom osvojiti." ${ }^{\text {"4 }}$ Pri ispitivanju državnog odvjetnika svjedok navodi da je te riječi koje je izrekao optuženi odmah zabilježio, pa ih iz svojih bilješki kazuje sudu. Međutim, na glavnoj raspravi svjedok Kušlić navodi da je riječi koje je izrekao optuženi upisao Pero Pavlić, a ne on. Prema njegovu iskazu vrijeme događaja bilo je u popodnevnim satima između 16 i 17 sati.

Drugi svjedok optužnice Gojko Gajić u istrazi je kazao da je stajao u crkvenom dvorištu do komandira Pavlića, a s prozora župnog stana optuženi je držao govor, pa je govoreći o križarstvu rekao: „Mene su pitali, kada su nas vidjeli u našim uniformama - šta je to, a ja sam im rekao, mi hoćemo samostalnu hrvatsku državu, koja nam se ne će dati, ako je ne će dati mi ćemo je silom osvojiti." ${ }^{\text {"5 }} \mathrm{Na}$ glavnoj raspravi svjedok je dao modificiranu izjavu te je naveo da je optuženi navedenog dana oko dva sata poslijepodne kazao sljedeće: „To su uniforme, koje traže zasebnu slobodnu Hrvatsku, koja nam se mora dati, ako nam se ne će dati, mi ćemo je silom uzeti." ${ }^{\text {"56 }}$

Treći svjedok optužnice Savo Stjepanović u istrazi je svjedočio da je optuženi dr. Protulipac navedenog dana rekao: „Kad smo došli u Brod, pitali su nas ko smo i kakve su to uniforme, a ja sam im rekao, da smo došli da oslobodimo Hrvatsku i Bosnu i hrvatsku katoličku Bosnu, nama se naše mora dati, a ako ne, mi ćemo je silom osvojiti." ${ }^{\text {"57 }} \mathrm{Na}$ glavnoj raspravi svjedok je iskrivio svoj iskaz te kazao da je optuženi rekao: „Mi smo oni, koji tražimo slobodnu nezavisnu posebnu hrvatsku državu, ako nam ne će dati milom, uzet ćemo je silom. ${ }^{\text {"58 }} \mathrm{Na}$ raspravi mu je predočen iskaz iz istrage, ali je svjedok izjavio da se ne može svega točno sjetiti te da je točno kako je u istrazi rekao.

Sljedeći svjedok optužbe bio je Ilija Čilić, koji je kazao da je optuženi u svome govoru rekao: „Braća Hrvati i Hrvatice, križari križarice, nama to nije dosta, jer mi hoćemo našu slobodnu Hrvatsku i ako neće milom mi ćemo silom",59 a svjedok Dedo Hadžiruflić kazao je na raspravi da se ne može točno sjetiti što je

54 HR-DAZ, fond Okružni sud u Zagrebu, Broj Kps. 3508-38, Presuda od 15. juna 1938.; HR-ALZ, kut. 3. „Križarska organizacija“.

55 HR-DAZ, fond Okružni sud u Zagrebu, Broj Kps. 3508-30, Presuda od 15. juna 1938.; HR-ALZ, kut. 3. „Križarska organizacija“.

56 HR-ALZ, kut. 3. „Križarska organizacija“; HR-DAZ, fond Okružni sud u Zagrebu, Broj Kps. 350830, Presuda od 15. juna 1938.

57 HR-DAZ, fond Okružni sud u Zagrebu, Broj Kps. 3508-30, Presuda od 15. juna 1938.; HR-ALZ, kut. 3. „Križarska organizacija“.

58 HR-DAZ, fond Okružni sud u Zagrebu, Broj Kps. 3508-30, Presuda od 15. juna 1938.; HR - ALZ, kut. 3. „Križarska organizacija“.

59 HR-DAZ, fond Okružni sud u Zagrebu, Broj Kps. 3508-30, Presuda od 15. juna 1938.; HR-ALZ, kut. 3. „Križarska organizacija“. 
optuženi govorio. Samo se sjeća da jedan u civilu za koga su rekli da je iz Zagreba, govorio: „Mi smo križari [...] mi ćemo je silom osvojiti.“60

Svjedok Tomislav Mesić na sudu je izjavio da tijekom navedene zgode optuženi inkriminirane riječi nije izrekao. Prema njegovim tvrdnjama, svjedok je predsjedao zboru, nazočio zboru i kao novinar bilježio sve događaje. Optuženi je rekao da će hrvatski narod moći konkordat sam osvojiti. Između ostaloga je rekao: „Kada su vidjeli ove uniformirane križarske čete, koje su stupale ulicama Bosanskog Broda, onda su mnogi pitali tko su ti, a ja im velim: To je nova mlada Hrvatska, to je hrvatska mladost, koja želi oslobođenje Hrvatske od svih mana i poroka, dakle svih negativnih elemenata njenog narodnog života. Konkordat je srušila beogradska ulica, ali je hrvatski narod toliko jak i snažan da će, ako ustreba, moći si ga izvojštiti." ${ }^{161}$

Svjedok Vjekoslav Švajger izjavio je da je optuženi govorio s prozora te ga u početku nije dobro čuo, ali se kasnije progurao jako blizu zgrade, i da optuženi nije izrekao inkriminirane riječi jer bi ih sigurno dobro čuo s obzirom na to da je bio u njegovoj neposrednoj blizini. Riječi koje je čuo su: „Neki nam ne daju konkordat. Mi milosti ne ćemo, ali ćemo si ga mi već uzeti.“"62

Slijedio je iskaz svjedoka Milivoja Mostovca, koji je bio u neposrednoj blizini dr. Protulipca, i to u sobi iz koje je govorio optuženi. Prema njegovu iskazu, optuženi je rekao da je najzdraviji put hrvatskog naroda vjera. Prikazao je križarsku organizaciju, koja za zadaću ima odgoj omladine. Rekao je da su križari Kristova vojska. Govorio je nadalje o konkordatu i rekao da će ga hrvatski narod sam osvojiti. Svjedok je na kraju kategorički rekao da optuženi nije rekao inkriminirane riječi. ${ }^{63}$

Preostali svjedoci dr. Smiljan Čekada, Ivica Mrgan, Ferdinand Fišer, Franjo Kuhar, Marija Stanković, Mate Vrkljan, Juraj Klantzer, Marijan Žnidaršić, Mirko Habulinec, Franjo Krajcar, Franjo Vlahov i Stjepan Globek rekli su da su slušali cijeli govor optuženog i da su bili u njegovoj neposrednoj blizini, ali da nisu čuli da je optuženi izrekao riječi koje mu se stavljaju na teret. Prema njihovim tvrdnjama, optuženi je govorio o vjerskom preporodu naroda, o idealima križara, o konkordatu, ali političke konotacije nije iznosio

60 HR-DAZ, fond Okružni sud u Zagrebu, Broj Kps.3508-30, Presuda od 15. juna 1938.; HR-ALZ, kut. 3. „Križarska organizacija“.

${ }^{61}$ HR-DAZ, fond Okružni sud u Zagrebu, Broj Kps. 3508-30, Presuda od 15. juna 1938.; HR-ALZ, kut. 3. „Križarska organizacija“.

62 HR-DAZ, fond Okružni sud u Zagrebu, Broj Kps. 3508-30, Presuda od 15. juna 1938.; HR-ALZ, kut. 3. „Križarska organizacija“.

63 HR-DAZ, fond Okružni sud u Zagrebu, Broj Kps. 3508-30, Presuda od 15. juna 1938.; HR-ALZ, kut. 3. „Križarska organizacija“. 


\section{GOVOR OBRANE}

Nakon izlaganja državnog tužitelja Maurovića, riječ je dobila obrana, pa je prvi govornik bio branitelj dr. Ivana Protulipca, dr. Dragutin Šafar, odvjetnik iz Zagreba, koji je vrlo iscrpno iznio obranu. Najprije je detaljno razložio i rastumačio smisao članka 3. Zakona o zaštiti države s pravne strane, a zatim je iskaze svjedoka povezao s radnjama te je došao do zaključka da je njegov branjenik nije ni počinio niti je mogao počiniti kazneno djelo prema optužnici, pa je svoju obranu završio tražeći da sud optuženog dr. Ivana Protulipca oslobodi svake krivnje i kazne. Zatim je riječ uzeo dr. Vladimir Cicak, drugi branitelj dr. Protulipca, koji je u pomno pripremljenom i nadahnutom govoru između ostaloga kazao sljedeće:

„Kad sam prije pet punih sati prestupio prag ove dvorane i uputio se braniteljskom stolu, bio sam uvjeren, da ću u svom obrambenom govoru morati slavnom sudu prikazati one ideje, koje već punih 20 godina propagira dr. Ivan Protulipac. Bio sam uvjeren, da ću morati slavnom sudu dočarati sliku razvitka cijelog pokreta, koji je zasnovao, razvio i kojem danas stoji na čelu dr. Ivan Protulipac. Međutim, sada, nakon netom izrečenog konačnog prijedloga, ja u glavnom više ne moram potanje prikazivati rad i ciljeve Križarstva. Međutim je g. državni tužilac tokom svoga obrazloženja konačnog prijedloga izvolio izreći jednu aluziju, iz koje proizlazi, kao da je taj pokret sa svojim odgovornim čimbenicima u zadnje vrijeme kao skrenuo s pravog puta na put svjetovne politike, a ovu svoju aluziju doveo je g. državni tužilac u vezu sa navodnim stavom nekih čimbenika. To me sili, da sa ovog mjesta branitelja izjavim odmah na početku svoga obrambenog govora, da pokret, kojemu je načelu dr. Ivo Protulipac nije do danas niti za jedan tren skrenuo s onog puta, na kojem ga vodi optuženi dr. I. Protulipca, te da su ideje, koje već skoro 20 godina propagira dr. I. Protulipac uvijek jedne iste. To su one ideje, koje je i g. državni tužilac prikazao u markantnim crtama i zato ja neću slavnom sudu te ideje prikazivati na način, kako sam to danas u jutro zamislio. Nakon ovakvog govora g. državnog tužioca ostaje mojom zadaćom pokušati dokazati slavnom sudu, da optuženi dr. Protulipac ne samo da nije izrekao onih riječi, koje mu u grijeh upisuje g. državni tužilac, već je optuženi dr. I. Protulipac tih riječi nije niti mogao izreći na križarskom zboru. Javni rad optuženog dr. I. Protulipca na području duhovne obnove hrvatske omladine predstavlja jednu periodu, koja je završila baš ovom godinom. U toj prvoj - baš ove godine - završenoj periodi, razabiremo tri odsjeka: Pet je godina proteklo u zdušnom pripravljanju današnjeg vođe pokreta za taj teški rad. Pet je godina radio u zajednici sad već pokojnim dr. Ivanom Merzom u bivšoj orlovskoj organizaciji, a deset godina radi dr. Ivo Protulipac sam, stojeći na čelu cijelog pokreta, koji se zove križarskim. U cijelom ovom dugogodišnjem radu ideološku je stranu pretežno obrađivao za svoga života 
danas već pok. dr. Ivan Merz, a organizatornu pretežno sam dr. I. Protulipac. Nakon smrti Ivana Merza obrađuje i jednu i drugu stranu sam dr. Protulipac, držeći ujedno sve niti cijelog pokreta i cijele organizacije u svojim rukama, razvijajući i organizaciju i pokret prema prilikama u narodu odnosno u domovini. Kroz cijelo ovo dugo razdoblje od punih 20 godina nije pokret nikada niti jedan tren skrenuo s puta, kojim ga je poveo dr. I. Protulipac. Razvijajući ideološku stranu pokreta, koji je iza njegove smrti dobio današnje ime 'križarski', pazio je pok. dr. I. Merz i te kako, da pokret ne zabludi na teren politike. Cijeli svoj život posvetio je pokojni dr. Ivan Merz izgradnji novog čovjeka. U omladini, koja će se tome uzvišenom poslu posvetiti, gledao je izabranu četu, četu Žrtve, Euharistije i Apostolata, četu koja će biti nosiocem živog djelotvornog katolicizma, služeći idejama i idealima vjere i domovine, kako je otvoreno i jasno izrekao vođa pokreta Dr. Protulipac na ovogodišnjoj Merčevoj proslavi u najvećoj dvorani grada Zagreba, baš na današnji dan, mjeseca svibnja. Baš pok. dr. Ivan Merz ustao je energično i otvoreno protiv svih onih, koji bi htjeli vjeru i crkvu zlorabiti u stranačko političke svrhe. Šta više, dr. Ivo Merz ustao je energično i protiv onih koji su svojim ličnim interesima i interesima svog užeg kruga htjeli zapostaviti interese Boga i domovine. Isti interes, koji je lebdio pred očima tako visoko moralnom čovjeku, kao što je bio jedan dr. Ivan Merz, za koga se već danas moli, da ga Crkva uzdigne u red blaženika, da ne kažem svetaca, isti naglasujem, interes lebdio je i lebdi stalno pred očima u njegovom javnom radu i današnjem vođi cjelokupnog pokreta dr. I. Protulipcu. Služiti Bogu i domovini predstavlja veliki ideal, koji je svima ljudima, koji su se za isti borili, donosio stalno najveće neprilike, izlažući ih uvijek neprestanim progonima. To nam dokazuje povijest. U svim narodima i u svim vjekovima bili su uvijek progonjeni oni pojedinci, koji su svoj život bili posvetili tome idealu...služiti Bogu i domovini. Progonili su takove pojedince uvijek kukavelji, mediokriteti, bijedne figure u sredini pojedenih naroda, koji su obično najuzvišenije ciljeve i ideale upotrebljavali kao sredstvo za postignuće svojih posebnih ciljeva. Dr. Ivo Protulipac progonjen je stalno i s lijeve i s desne strane. S lijeve mu strane predbacuju, da je klerofašista i prijatelj, saveznik kapitalista, a s desne ga strane sumnjiče, da je revolucionarac, jer traži od katolika najprije djela, a onda ljubav. Kada je došao 6. siječanj 1929. prvi je bio na udaru dr. Ivo Protulipac, sastavljač prvih pravila križarske organizacije. Neprijatelji s desne strane prikazali su tadanjem predsjedniku vlade g. Peri Živkoviću kao opasnog po novi državni poredak, koji je utvrđen 6. januara 1929. G. Pera Živković opazio je u tim pravilima, da će se križari baviti uz ostalo i 'duhovnim vježbama', pa kako je raspustio sva tjelovježbena društva, a duhovne vježbe zamijenio sa tjelovježbom, smatrao je dr. Protulipca krivcem, jer da unatoč njegove zabrane pokušava osnovati ‘tjelovježbena' društva. U to vrijeme i pomoću g. Pere Živkovića trebalo je zadati prvi udarac križarskoj organizaciji. Poveden je postupak po zakonu o 
zaštiti države. Dr. Protulipac bio je uhvaćen, sproveden najprije u uze zagrebačkog redarstva, a odatle nakon nekoliko teških dana u uze ovoga suda. Postupak sudski vodio se pod oznakom Kzp, 606-30 no morao je biti razvrgnut, a dr. I. Protulipac pušten na slobodu. Prvi plan neprijatelja križarske organizacije za napad na dr. Ivana Protulipca pao je brzo u vodu. To je bilo, slavni sude, u prvoj godini diktature, dakle odmah nakon 6. Januara 1929., kada je nestalo nezavisnosti sudaca. Kada je izišao prvi broj križarskog mjesečnika pod naslovom 'Križ' s programatskim člankom vođe križara dr. Protulipca pod naslovom 'U znaku križa' opet je proti njemu pokrenut krivični postupak. U tom programatskom članku sadržane su u zbitoj formi sve one ideje, koje je dr. Protulipac propagirao kroz 20 godina i koje je propagirao na svim zborovima, na kojima je do danas nastupio, pa tako i na zboru u Bos. Brodu, o kojem je na ovom pretresu riječ. Radi tog članka odnosno ideja razvijenih $u$ tom članku optužen je ponovno dr. Protulipac i opet po zakonu o zaštiti države, pa je baš ovaj okružni sud pod br. Kps 427/31 riješio Dra Protulipca svake krivnje ne našavši u tome članku ništa, što bi bilo protivno pozitivnim zakonima države. U svom obrazloženju navodi ovaj okružni sud, da one rečenice iz tog članka, za koje je tužen, da baš u njima nije sud našao ništa opasnoga. Te su rečenice prema obrazloženju odnosne presude ove: 'U velikom mimohodu naroda pokraj Križa i Golgote prošao je u svojoj tisućljetnoj prošlosti hrvatski narod. Dok smo mi u vjekovima stajali kao križari, naoružani mačem, da branimo zapad, nijesmo mogli niti smo imali vremena da potpuno izgradimo našu kršćansku kulturu. Neprijatelji križa dobro su to iskoristili. Zasijali su korov. Taj korov oni i dalje neprestano siju. Danas je u naponu taj pokret protiv križa. Judejska, beznačelna i trgovačka štampa, udruženja, i brojni drugi faktori su u akciji. Putem našeg narodnog života treba odlučno okrenuti. Krivulju, koju su zacrtala posljednja desetljeća treba zaustaviti i cio naš narodni život dovesti u puni sklad sa historijskom orijentacijom našom, našega naroda. Da se život Hrvata do dna združi sa crkvom katoličkom i da se na tom temelju razvijaju i dalje plemenite i lijepe naše narodne osebujnosti. Takav, katolički, narodni život, treba da ostvare nove generacije, koje dolaze i već su njihovi prvijenci u našoj sredini. Križ i nauka crkve mora opet postati središte mišljenja i pogleda našega naroda. Da li će nas razumjeti da je danas posljednji čas za opću, skupnu akciju za naše katoličko osviještenje!? Tko će biti kriv, ako se propusti ovaj odlučni čas, kada se dade spasiti jedinstvo našeg narodnog života sa živom katoličkom vjerom i crkvom? Ovaj crkveni, katolički smjer želimo da prihvati sav naš narod. Taj smjer mora u narodu provoditi naša mladost, koja se nikada nije bojala niti prezala pred teškoćama. Program je te omladine jasno vidljiv u Kristovu križu. On znači najsavršeniju demokraciju svijeta. A teškoće? Mi ih vidimo! Ali iza Velikog Petka dolazi Uskrs!Vjerom pobijediše junaci kraljevstva, ugasiše silu ognjenu, rastjeraše vojsku: Mi hoćemo i Veliki Petak, da dođe tim sjajniji Uskrs! 
Eto slavni sude, u ovih nekoliko riječi želim kazati da cijeli program križarske organizacije, cijeli program pokreta onog dijela hrvatske omladine, koju danas pod imenom križarskim vodi dr. Ivan Protulipac. Tu su sadržane sve one ideje i isključivo samo one ideje, koje stalno propagira tokom 20 skoro godina dr. Protulipac. On može mijenjati pojedine riječi, no sadržaj, smisao ostaje uvijek isti.' Godine 1935. i 1936. neprijatelji križarske organizacije opet su pokušali, da ciljeve Križarstva krivo tumače. Baš zato održao je dr. Protulipac u Zagrebu god. 1936. na velikom križarskom zboru pred mnogo hiljada slušatelja značajan govor, u kome je ponovno prikazao misli vodilje križarskog pokreta. Citirat ću iz tog velikog govora dr. Protulipca ova značajna mjesta: 'Hrvatsko križarstvo neće ništa drugo, nego da po duhu i životu obnovi onu Hrvatsku i one Hrvate, kakvi su bili Hrvati Tomislava i tvorci osnova našeg narodnog života kroz stoljeća. Križarstvo ne ulazeći u političke i državno-pravne probleme, koji na njega ne spadaju, upozorava, da narodi imadu onakav život, kakva su im pokoljenja i kakvi su im ljudi koji ih čine. A mi želimo, da se vrate po duhu, srcu i životnoj snazi ona pokoljenja, koja su formirala naš život i dala nam sve što imamo bitno u našem duhovnom i duševnom uobličenju. I zato ćemo biti jaki, neustrašivi, mrski svima, koji su zli i pokvareni, otporni svemu, što je nastrano i zlo, ali blagi prema onima, koji su vrijedni članovi našeg narodnog života. Neustrašivi i neumoljivi neprijatelji onih, koji ruše poštenje i moral hrvatskom narodu. Hoćemo smrt pokvarenosti, nemoralu, nepoštenju! Hoćemo da uništimo izvore tih zala, koja nam upropašćuju omladinu našu. Hoćemo pokoljenja straha i ljubavi Božje, poštenja, junaštva, koje će gore valjati, vihorima prkositi, poznavati samo put naprijed i naprijed. Hoćemo smrt sebičnog duha, jevrejsko-kapitalističkog izrabljivanja, da bi zavladala ljubav, ali prije svega pravda'. Evo, slavni sude, i u ovom velikom govoru dr. Protulipca iz god. 1936. i opet iste misli, propaganda uvijek istih ideja, tek sa izmijenjenim riječima! Konačno, imamo i zadnji javni govor dr. Protulipca od 15. svibnja 1938. pred tisućama slušalaca u najvećoj dvorani grada Zagreba u Zagrebačkom zboru: 'O mislima i djelima novog hrvatskog pokoljenja u radu za Boga i Hrvatsku'. Djelujući u hrvatskoj omladini kroz 20 punih godina kao vođa ove omladine razvijajući u ovom velikom vremenskom odsjeku i samoga sebe i svoje sposobnosti, došao je konačno dr. Protulipac do uvjerenja, da je s ovom godinom završio jedan period svoga rada i da ulazi na vrata novog jednog perioda u kojem će poći istim putem, propagirajući iste ideje, tek možda u promijenjenim prilikama. Na svršetku ovog prvog perioda svoga rada u sredini hrvatske omladine neobično je iskren, pa u svom govoru veli ovo: 'Tragični su dani, kada narodi dožive slomove svojih političkih i gospodarskih težnja. Srce svakoga živoga naroda krvari, ako on izgubi svoju političku slobodu ili pade u ropstvo tuđe gospodarske premoći i izrabljivanja. Ali historijska je istina i to, da narodne političke ili gospodarske tragedije nikada nijesu trajne. Da narodi redovno nikada ne izgube života i ne 
umiru pod nedaćama svojih političkih poniženja i materijalnih slomova. Božja pravda nikada ne napušta pojedince ni narode, koji su bez svoje krivnje pali u nevolje i poniženja. Zato povijest, kada bilježi slomove i smrti velikih i malih naroda, redovno konstatira, da su uzroci smrti drugi, nego li vanjska sila ili materijalna nevolja. Maleni hrvatski narod nije propao u crnim vjekovima najtragičnije političke sudbine ili gospodarskog potlačivanja za mletačke, turske, madžarske i brojnih drugih najezda samo zato, jer je imao zdravu i krepku, solidno izgrađenu i ničim ne zaraženu narodnu dušu. Gigantska borba naroda u današnjici jest borba da pojedini narodi nađu svoju narodnu dušu, da obnove porušene narodne ideale i postanu sami gospodari svoga života i svoje slobode. Kod nas je aktuelno pitanje u ovim burnim vremenima, da naš katolicizam bude stvarnost, ne samo po opredjeljenju, nego i po stvarnom životu pojedinaca. Da svaki pojedinac po njegovim načelima živi i radi. A onda i drugo pitanje: da se naš katolicizam i dalje sačuva kao dobro naše nacionalne sredine i da se nikada ne zatvori u krug jedino vjernih, koji će se ograditi zidom nepovjerenja, grupaštva i klikaštva od nacionalne naše sredine. Ovakav, preporodni katolicizam, koji tiho ulazi u duše, da u njima ostvari revoluciju duha u novoga čovjeka, jest životni program jednoga od najvećih Hrvata, velikoboraca za Božjeg čovjeka dr. Ivana Merza.' Dr. Ivo Protulipac govorio je da do danas najmanje na 500 velikih javnih zborova u svim krajevima Hrvatske i Slavonije, Dalmatinske Hrvatske, te Bosne i Hercegovine. Ako uzmemo da je na svakom od tih zborovanja sudjelovalo samo po 2000 slušatelja, dobivamo ogromnu brojku od jednog miliona slušatelja. Na svim tim zborovima propagirao je dr. Ivo Protulipac uvijek jednu te istu ideju, ovu kakovu sam do sada pred Vas, gospodo suci, iznio u riječima dr. Protulipca iz njegovih najmarkantnijih govora u raznim odsjecima vremena. Nikada se nije niti najmanji incident a bilo je zborova, na kojima sam i ja bio prisutan, a na kojima je sudjelovalo i 20 i 30 hiljada ljudi. Nikada nije trebala uredovati državna vlast, koja je na svakom pojedinom od tih mnogobrojnih zborova bila i te kako dobro zastupana! U vremenima, u kojima plaćenici razornog i nemoralnog boljševizma upiru svoje oči i šalju svoje plaćenike među omladinu pojedinog naroda, da ju zarobe za svoje razorne ideje, i da ju učine robovima svojih gospodara, baš u tim vremenima okuplja dr. Ivo Protulipac oko sebe na desetke hiljada hrvatske omladine, da ih spasi...Bogu i domovini. Omladina ide tim putem samo i jedino zato, jer osjeća, da je put, kojim ide dr. Ivo Protulipac, put poštenja, istine, pravde i ljubavi. Kada sve to, što sam sada u glavnim crtama spomenuo, uzmete u obzir, pa kada ćete za koji čas odvagnuti u Vašoj nutrini, gospodo suci, iskaze svjedoka optužbe i obrane, molim sjetite se, da ćete izreći presudu nad čovjekom, koji je cijeli svoj život posvetio Bogu i svojoj hrvatskoj domovini, šireći u srcima svoje omladine poštenje, istinu, pravdu i ljubav. Izreći ćete presudu nad čovjekom, koji živi i radi, muči se i trudi, izložen istodobno napadajima s lijeva i s desna, samo i 
jedino zato, jer želi ostati vjeran Bogu i hrvatskom narodu. Mnogo je već nepravde prohujalo nad glavom vođe jednog djela hrvatske omladine na putu duhovne obnove, dr. Ive Protulipca. Uvjeren sam da će danas u ovoj dvorani pravde za koji čas pobijediti pravda, pa zato mirno mirne duše očekujem pravorijek slavnoga suda, a i moj branjenik očekuje taj isti pravorijek! Ja sam svršio!“64

\section{OBRANA DR. IVANA PROTULIPCA}

Nakon izlaganja i obrane dr. Vladimira Cicka uslijedio je govor dr. Ivana Protulipca koji je u svoju obranu iznio sljedeće činjenice: „Bit inkriminacije, koju protiv mene iznosi g. državni tužilac na osnovu prijave policijske straže u Bos. Brodu od 22. VIII. 1937. jest u tome da sam rekao u Bosanskom Brodu, govoreći o Križarstvu:

'Mi Križari kad smo došli u ovo mjesto, na euharistijski kongres, mnogi kad su nas vidjeli u našim uniformama, pitali su nas, tko smo, što smo i što hoćemo, a ja im kažem, da hoćemo samostalnu hrvatsku državu, koja nam se mora dati, a ako nama se neće dati, mi ćemo je silom osvojiti.' Prema ovoj inkriminaciji imao sam ja, kao predsjednik križarske organizacije, na odgovornom mjestu, na zboru organizacija označiti kao svrhu organizacije (kao ono, što odgovara na pitanje: Tko smo i što hoćemo): 'da hoćemo samostalnu hrvatsku državu, koja nam se mora dati, a ako nam se neće dati, mi ćemo je silom uzeti. Po ovom bi svrha križarske organizacije, po meni kao njezinom predsjedniku bila, borbom, milom ili silom za samostalnu hrvatsku državu. Optužba g. državnog tužioca sili me, da sa posve principijelnog gledišta iznesem poglede, koje organizacija Križara imade na probleme nacionalnog i političkog života, da bi se moglo pravo ocijeniti uopće samu mogućnost ovakve izjave, jer niti g. državni tužilac valjda ne želi ostati kod svoje optužbe onda, ako se ustanovi, da ovakva izjava o svrsi križarske organizacije sama po sebi nije mogla ni pasti od mene, koji svrhu organizacije poznam i tumačim ju već više od 15 godina hrvatskoj omladini i hrvatskom narodu. Gospodo suci! Nedvojbeno je pravo svakog naroda, da se na svom teritoriju može slobodno razvijati i sam odlučivati svojom sudbinom. U suverena prava svakoga živoga naroda spada, da određuje svoju unutarnju i vanjsku politiku, te da se po tom brine za što bolje uvjete svoga napretka. Međutim ne smije se nikada zaboraviti, da sva teoretska prava naroda vrijede u stvarnom životu samo onoliko, koliko je narod sam u sebi snažan i moćan, da svoja prava dovede do stvarnosti, da 
ih provede u život. Prema tome i vanjska i unutarnja politika naroda, bio on ma koji na svijetu, vrijedi samo toliko, koliko vrijedi narod, koji je njezin nosilac. Spretnost, himba, prevara, čudovite zgodne kombinacije itd. mogu samo za neko vrijeme pribaviti neku političku korist. Redovno su sve ovakove koristi prividne i od njih dolaze narodima na koncu samo teška iskušenja i stradanja. Baš zato bi u životu teško stradali narodi, koji bi sve očekivali od politike i sve svoje energije usredotočili samo na teren političkih borbi. Snažna i uspješna je politika samo onoga naroda, koji ima u sebi izgrađene one primarne vrednote, koje čine čovjeka vrjednijim, boljim, naprednijim i sposobnijim. Više kvaliteta što većeg broja pripadnika naroda znači isto, što i bolji njegov napredak, snažniji njegov uspjeh svuda, pa i u politici. Baš zato, bi u životu teško stradali narodi, koji bi sve očekivali od politike i sve svoje energije usredotočili samo na teren političkih borbi. Snažna i uspješna je politika smo onoga naroda, koji imade u sebi izgrađene one primarne vrednote, koje čine čovjeka vrijednijim, boljim, naprednijim i sposobnijim. Viša kvaliteta što većeg broja pripadnika naroda znači isto, što i bolji njegov napredak, snažniji njegov uspjeh svuda, pa i u politici. Baš zato, jer je rad na stvaranju kvaliteta u ljudima primarniji, on je u biti važniji od svakog drugog rada. Vrednote ovoga rada nalaze se u prvom redu u carstvu duha. Treba stvoriti dobrog, vrijednog, značajnog čovjeka. Taj čovjek mora biti socijalan, napredan i kulturan, a u ekonomiji i službi za dnevni život mora biti radin i suvremen. Briga oko ove izgradnje čovjeka bitno se ne može povezati s nijednom nutarnjo-političkom ili vanjsko-političkom aktivnosti. Ta izgradnja osniva se na vrednotama, koje nisu niti mogu biti ovisne o političkim oscilacijama. To su trajne vrednote duha, neovisne o prilikama i političkim kombinacijama. U nizu ustanova, koje u hrvatskom narodnom životu rade za izgradnju čovjeka duha, kulture i čovjeka duboko socijalnog spada i križarska organizacija. To su trajne vrednote intenzivne religiozne izgradnje. $\mathrm{Na}$ toj osnovi križarska organizacija izgrađuje čovjeka u svemu onom, što je bitno i odlučno da bude čovjek na svom mjestu. Stoga čovjekKrižar mora biti najprije značajan čovjek. Za njega život vrijedi samo kao jedan dio drugoga puta i za taj život on odgovara Bogu i njegov život mora biti usklađen zakonima ljubavi Bogu i bližnjemu. Stoga on mora biti čelični nosioc istine, morala i pravednosti. To je temelj na kojemu se sve gradi. Dakako da taj čovjek-Križar mora biti i čovjek znanja. Napredan, spretan i spreman. On mora biti prožet duhom pravednosti u međusobnim socijalnim odnosima. Pa onda radin, jer mu je rad dužnost po Bogu određena, kao dio životne misije. Križarska organizacija tu stoji. Ona po svojoj naravi ne može saći na područje aplikacije, jer je izgradbena i uzgojna. Ona postavlja čovjeku načela za život i davši mu spremu i svijest o socijalnim dužnostima, očekuje od njega, da će svoju dužnost ispuniti. Samo ovo izlazi iz pravila i prakse križarske organizacije. Samo ovo se tumači na zborovima, kongresima i sastancima. To svaki Križar znade, to je abeceda njegova gledanja na 
bit i svrhu njegove organizacije. I nacionalno uvjerenje i nacionalni uzgoj osnovan je posve u okviru ovih načela. Ljubav prema narodu i domovini je moralna dužnost. Isto tako, kako čovjek ne smije biti nepošten prema ocu i majci i ne priznati ih, napustiti ih, tako i prema domovini i prema narodu imade moralnu obavezu ljubavi i rada. Stoga je prirodno, da će križarska organizacija svog člana učiti ljubavi prema hrvatskom narodu i domovini, jer je to stvar moralne obveze. Posve je prirodno, da je ovaj rad križarska organizacija protegla samo do granice lične formacije čovjeka. Ona po strogom slovu svojih pravila i po cijeloj praksi stoji na stanovištu, da na nju spada samo ono, što je čovjeku trajno. Stoga organizacija ne samo u općim načelima, nego i u praksi odlučno odbacuje političko opredjeljenje i miješanje. Njezini ciljevi i postignuće tih ciljeva nije vezano u biti za nijedno državno-političko stanje ili režim. To su načela na kojima počiva cio ovaj rad. Posve je prirodno, da ni ja, govoreći na zboru organizacija, o njezinim ciljevima, nijesam mogao o ciljevima organizacije govoriti drugo, nego ono, što svaki član pozna kao cilj organizacije. Nijesam mogao drugu svrhu postaviti ni članstvu, sakupljenom u Bos. Brodu, jer bi inače govorio ne samo ono, što ne stoji, nego bi govorio ono, što svaki član znade da nije tako. Položaj hrvatskog naroda, njegove patnje i boli su na srcu svakog člana križarske organizacije. Mi kao djeca hrvatskog naroda živimo s njim, patimo s njime is njime ćemo na Kalvariju i do Uskrsnuća. O tom nema nikakve dvojbe. Naša lična mišljenja o političkim problemima hrvatskog naroda po tome ne mogu biti druga, nego ona najboljih sinova hrvatskog naroda. Ali mi dobro znamo, gdje što spada. Mi znamo, da hrvatski narod probleme svog političkog opstanka ne može rješavati u crkvama i sobama, gdje se izgrađuje - osnovne vrednote hrvatskog narodnog života. Mi smo uvijek naglašavali i naglasujemo i danas: Faktori, koji izgrađuju dubine vjerskog života, ne smiju biti nosioci nijednog političkog rada. Ako je itko, a ono sam baš bio ja prvoborac u tom radu, da se vjera i vjerske ustanove ne uvlače na teren aktivne politike bilo u kom pravcu i bilo tko ju vodio. Zato sam trpio progone i danas ih trpim. Kada bih htio u ovoj bitnoj točki svoje životne aktivnosti promijeniti kaput, riješili bi se ja i moji drugovi mnogih teškoća i borba, koje nas prate. Ali mi znamo vrijednost načela za koje se borimo. A možete, biti uvjereni gospodo suci, da ću ja biti među posljednjima, koji ću vjerskim i crkvenim ustanovama odobravati, da pređu preko svoga određenog djelokruga i Križarima. Prema tome gospoda, policijski organi g. ministra unutarnjih poslova obratili su se na posve krivu adresu, kada su baš meni pripisali ove političke izjave. I to još na križarskom zboru. Kada bih ja htio i želio dati političke izjave, izjave o svojim nacionalnim vjerovanjima i gledanjima, onda bi ih dao na mjestu gdje one spadaju i sigurno ne kao predsjednik križarske organizacije. Za danas ta mišljenja nisu izrečena, posebno ne pred predstavnicima policijskih vlasti, a de internis non iudicat praetor!(O onomu što tko misli sud ne može suditi). I državna optužba, da je htjela provjeriti same 
mogućnosti ovakvog mog govora kao predstavnika križarske organizacije, te da se obratila na crkvenu vlast, dobila je odgovor, da sve, što mi se upisuje u grijeh, nijesam mogao reći, jer to je protivno logici stvari. Među crkvenim faktorima našlo bi ih se, koji bi sigurno tražili, da me se skine s mjesta voditelja križarskog rada, kada bih ovako govorio o crkvenim udruženjima i o njihovoj svrsi. Ali svatko upućeni znade da ovakove izjave, ovakovo padanje na lijepak ne može poteći od mene. Pronašao sam ja mnogo gorka, mnogo prilika, ali sam iz njih izišao cio. Jer sam znao dobro razlikovati što kamo spada. Zato ni g. Pera Živković uza sve nastojanje nije mogao da mi dokaže ono, što je htio da bi uništio sav moj životni posao. On me je gonio, ali na koncu popustio. Vidio je, da borci duha ne padaju pred žandarskim prijavama. I ja sam kroz klance-jadikovce njegove periode vladanja vodio ovu idealnu križarsku omladinu. Pokušali su tom djelu dati političku boju i neki drugi! U zadnje vrijeme pače i jedan svećenik u cijeloj knjizi o tom napisanoj. Ali uzalud, ne može se zamračiti rad, svijetao kao sunce. Ne će taj rad zasjeniti ni policijski organi iz Bos. Broda ni ova optužnica g. državnog tužioca. Ono što je istina, ostaje uvijek istina uvijek, ma kakove sjene došle.' ${ }^{35}$

\section{PRESUDA U IME NJEGOVA VELIČANSTVA KRALJA!}

Nakon govora dr. Ivana Protulipca sudsko vijeće kratko se povuklo na vijećanje te se potom vratilo u raspravnu dvoranu i donijelo sudsku presudu. Veliko vijeće Okružnog suda u Zagrebu u sastavu Vilko Boroša, predsjednik, Andrija Žic, član, i Rudolf Somer, član, te dr. Žarko Vimpulšek, odvjetnički pripravnik kao zapisničar u optužnici državnog tužitelja koju je zastupao dr. Benjamin Maurović, zbog članka 3. Zakona o zaštiti javne bezbednosti i poretka u državi je donijelo sljedeću presudu:

'Optuženi Protulipac Dr. Ivan, 38. god. star, sin Janka i Doroteje rođ. Bezjak, rkt. vjere, rodom iz Karlovca s prebivalištem u Zagrebu, jugoslavenski državljanin, advokat, neoženjen, pismen, vojsku je služio, bez imetka, neosuđivan. Na osnovi čl. 280 od 1-kp oslobađa se optužbe, da je 22. augusta 1937. god. u Bos. Brodu pred zborom križarskih društava i ostalim građanima, koji su učestvovali na euharističkom kongresu u svom govoru među ostalim rekao i slijedeće: „Mi Križari, kad smo došli u ovo mjesto na euharistički kongres, mnogi kad su nas vidjeli u našim uniformama, pitali su se tko smo, što smo i što hoćemo, a ja im kažem, da hoćemo samostalnu hrvatsku državu, koja nam se mora dati, a ako nam se ne će dati, mi ćemo je silom osvojiti, pa je dakle govorom pred sakupljenom masom vršio propagandu i išao za tim da stvori ubeđenje i raspoloženje kod

65 HR-DAZ, fond Okružni sud u Zagrebu, Broj Kps. 3508-30, Presuda od 15. juna 1938.; HR-ALZ, kut. 3. „Križarska organizacija“. 
prisutnih da se neki dio Kraljevine Jugoslavije izdvoji iz cjeline kao samostalna država, pa da je time učinio zločinstvo iz čl. 3 zakona o zaštiti javne bezbednosti i poretka u državi. Trošak krivičnog postupka snosi državna blagajnica na osnovi čl. $311 \mathrm{kp}^{366}$

U obrazloženju sudske presude sud se vodio činjenicom da je optuženi iznio činjenice koje opovrgavaju optužnicu. Naime, prema obrazloženju suda, dr. Protulipac je navedenoga datuma govorio samo o konkordatu, koji Hrvati zapravo nisu dobili s obzirom na ustroj tadašnje države i na činjenicu da je Hrvatska bila u sastavu Kraljevine Jugoslavije, te su prema tome i težili „ali da će ga oni imati, da će ga znati izvojštiti, jer imaju za to sile i snage“. Iz takve konotacije pojedinci su lako mogli zaključiti da se njegov iskaz odnosi na političku konotaciju, a ne na vjersku, zbog čega su ga i prijavili.

Uzimajući u obzir iskaze svjedoka, sud je našao da optuženog terete samo svjedoci Rajko Kušlić, Gojko Gajić, Savo Stjepanović i Ilija Čičić. Međutim, sud navedenim iskazima nije poklonio vjeru jer su dijametralno suprotni od iskaza koji su dali u istrazi. Tako redom iskazi svjedoka Rajka Kušlića, Gojka Gajića i Save Stjepanovića u istrazi nisu suglasni s njihovim iskazima na glavnom pretresu, zaključak je sudskog vijeća. Naime, svjedok Kušlić u istrazi je kazao da je inkriminirane riječi odmah zabilježio pa ih iz svojih bilježaka sudu govori, dok je na glavnom pretresu kazao da on nije inkriminirane riječi zapisao, već Pero Pavlić. ${ }^{67}$

Svjedok Gojko Gajić u istrazi je rekao da je optuženi izrekao: „mi hoćemo osloboditi Hrvatsku, koja nam i pripada i moraju nam je dati, jer ćemo to inače silom učiniti“, dok je na glavnom pretresu rekao da je optuženi rekao „to su uniforme, koje traže zasebnu slobodnu Hrvatsku, koja nam se mora dati, jer ćemo je inače mi silom uzeti“ 68

Treći svjedok optužbe Savo Stjepanović u istrazi je rekao da je optuženi izrekao „došli smo da oslobodimo Hrvatsku, Bosnu i hrvatsku katoličku Bosnu, nama se naše mora dati, a ako ne mi ćemo je silom osvojiti“, a kasnije, nakon što mu je predočen iskaz, svjedok je izjavio da se točno ne sjeća što je optuženi rekao, ali da ostaje kod svoga iskaza u istrazi. ${ }^{69}$

66 HR-DAZ, fond Okružni sud u Zagrebu, Broj Kps. 3508-30, Presuda od 15. juna 1938.; HR-ALZ, kut. 3. „Križarska organizacija“.

67 HR-DAZ, fond Okružni sud u Zagrebu, Broj Kps. 3508-30, Presuda od 15. juna 1938.; HR-ALZ, kut. 3. „Križarska organizacija“.

68 HR-DAZ, fond Okružni sud u Zagrebu, Broj Kps. 3508-30, Presuda od 15. juna 1938.; HR-ALZ, kut. 3. „Križarska organizacija“.

69 HR-DAZ, fond Okružni sud u Zagrebu, Broj Kps. 3508-30, Presuda od 15. juna 1938.; HR-ALZ, kut. 3. „Križarska organizacija“. 
$S$ obzirom da iskazi svjedoka nisu bili vjerodostojni, tj. nisu korespondirali $\mathrm{s}$ iskazima koje su dali u istrazi, suglasni sud nije povjerovao iskazima istih svjedoka. Jednako tako, sud nije poklonio vjeru iskazu svjedoka Ilije Čičića, jer je isti, kao i iskazi trojice navedenih svjedoka, bio oprečan u odnosu na iskaz koji je dao u istražnom postupku. Sud je smatrao da su svjedoci koji su između ostalih čuli i riječi kao „Hrvatska“, „konkordat“, „, slobode“, ,silom“ pa su iste spojili tako da idu u posve drugi kontekst, tim više jer su svjedoci niže obrazovani, s jedva četiri razreda osnovne škole, pa nisu shvatili ideje i pojmove koje je optuženi u svom govoru, koji je brzo govorio, izlagao.

Osim toga, sud je smatrao da iskazi spomenutih svjedoka obrane ukazuju na okolnost što se tijekom kritične zgode nije održavao politički zbor, već zbor križarskih društava, kojima je svrha vjerski preporod i poštenje, pa nije logično da bi optuženi na takvom jednom zboru govorio da treba izvojštiti silom slobodnu hrvatsku državu. S obzirom da sud nije mogao utvrditi takve činjenice koje bi nesumnjivo upućivale da je dr. Ivan Protulipac izgovorio inkriminirane riječi, u pomanjkanju dokaza oslobodio ga je od optužbe.

\section{ZAKLJUČAK}

Sudski postupci koji su vođeni protiv dr. Ivana Protulipca, odvjetnika i katoličkog intelektualca te dugogodišnjeg predsjednika Velikog križarskog bratstva, govore o ozbiljnoj namjeri aktualne vlasti i iracionalnim postupcima političkog režima Kraljevine Jugoslavije. Dr. Ivan Protulipac odmah je nakon zabrane Hrvatskog orlovskog saveza zajedno sa svojim suradnicima u siječnju 1929. godine tražio način kako osnovati novu katoličku organizaciju koja će imati kontinuitet u Hrvatskom orlovskom savezu koji je zajedno s dr. Ivanom Merzom i ostalima osnovao 1923. godine.

Odmah nakon osnivanja Križarske organizacije u siječnju 1930. godine, dr. Protulipac bio je izložen drastičnom pritisku vlasti i uhićen 27. siječnja 1930. godine. Uhićen je i sproveden u policijsku stanicu gdje je cijeli dan trajala istraga. Zapisnik koji je kod policije sastavljen govori o naravi i karakteru uhićenja dr. Protulipca. Bio je optužen da je unatoč zabrani htio osnovati „tjelovježbena“ društva. Proveden je postupak po Zakonu o zaštiti države prema kojemu je bio uhićen i proveden sudski postupak koji se vodio pred Kotarskim sudom u Zagrebu pod brojem Kzp. 606-30., od 27. siječnja 1930., ali je predmet bio odbačen, a dr. Protulipac oslobođen. U siječnju iste godine izišao je prvi broj mjesečnika Križ s programatskim člankom dr. Ivana Protulipca pod naslovom: 
„U znaku križa“ te je ponovno policijski režim promptno djelovao te se tražilo tko je autor i tko su članovi uredništva i konzorcija društva. Opet je protiv njega pokrenut kazneni postupak. U istom članku sadržane su zapravo sve one ideje koje je dr. Protulipac propagirao kroz dvadeset godina svoga javnog djelovanja. Upravo zbog istoimenog članka bio je optužen prema Zakonu o zaštiti države pa je u predmetu pred I. Kr. Kotarskim sudom 13. siječnja 1931. godine vođen postupak. Međutim, u žalbenom postupku pred Kr. sudbenim stolom, tj. Okružnim sudom u Zagrebu, br. Kps 427/31., Protulipac i njegovi suradnici bili su oslobođeni svake optužbe jer Sud nije mogao pronaći ništa nezakonito.

Unatoč kontinuiranom progonu kojemu je bio izložen kao predsjednik Velikog Križarskog Bratstva, dr. Ivan Protulipac nije odustao od nakane da radi za interese mladih i Katoličke crkve. Nastojao je ostvariti sve ono što je još za života pa sve do svoje smrti naučavao bl. Ivan Merz. A to je djelovati i živjeti prema načelima Katoličke akcije Pape Pija XI. koju je u Crkvu u Hrvata prvi uveo upravo bl. Ivan Merz. Njezin su program kasnije provodili u život mnogi mladići i djevojke diljem Hrvatske.

U svojem nadahnutom govoru pred brojnom katoličkom mladeži na Euharistijskom kongresu 22. kolovoza 1937. godine u Bosanskom Brodu, ponovno je postao predmetom istrage režimskih vlasti. Uhićen je i optužen zbog kaznenog djela iz članka 3. Zakona o zaštiti države Kraljevine Jugoslavije za koje je djelo državni tužitelj tražio kaznu od pet godina. Međutim, i taj puta, kao i u svim ostalim prigodama, dr. Protulipac bio je ustrajan u dokazivanju istine za koju se borio. Unatoč svjedocima režima koji su svjedočili protiv njega, sud nije pronašao elemente za kazneni progon i osuđujuću presudu pa je Protulipac ponovno oslobođen svih optužbi.

Protulipac je u svim svojim javnim nastupima bio vizionar, čovjek vjere i čovjek za vjeru i bližnjega. I danas su aktualne njegove riječi koje je izrekao na Papin dan 1936.: „Budimo uvjereni da sretna budućnost naša i hrvatskog naroda stoji najprije do milosti svemogućeg dobrog Boga. Uzalud nam napori i žrtve, ako ne gradimo s Bogom.“ 


\section{IZVORI I LITERATURA}

\section{IZVORI:}

\section{HR-Hrvatski državni arhiv (HR-HDA), Zagreb}

Fond: Savska banovina, Državna zaštita, kut. 7., br. 24868/1931., Uprava policije u Zagrebu.

Fond: SB DZ Pov. br. 24868/1931., Uprava policije u Zagrebu.

Fond: Kraljevska banska uprava Savske banovine, Otsek za državnu zaštitu, Pov. II. D. Z. broj 8509-1935.

\section{HR-Arhiv hrvatske biskupske konferencije, (HR-AHBK), Zagreb}

Fond Katolička akcija, Pismo s prilogom dr. Ivana Protulipca, predsjednika HOS-a preuzvišenom gosp. dr. Antunu Baueru, zagrebačkom nadbiskupu, od 28. XII. 1923.

Fond Katolička akcija, Pismo dr. Ivana Protulipca, predsjednika i Jerolima Malinara, tajnika HOS-a, preuzvišenom gosp. dr. Antunu Baueru, zagrebačkom nadbiskupu, od 28. XII. 1923.

Posebni fascikl, „Katolička Akcija - Orlovi - Križari“, 36., Žalba Ministarstvu unutarnjih poslova u Beogradu zbog progona Križara.

\section{HR-Državni arhiv (HR-DAZ), Zagreb}

Fond: Kzp. 606-30., Prijava državnog odvjetništva Zagreb.

Fond: Kps 427/31, Okružni sud u Zagrebu, Sudska presuda od 14. 02. 1931.

Fond: Okružni sud u Zagrebu, Broj Kps. 3508-38, Presuda od 15. juna 1938.,

HR-Arhiv dr. Lava Znidarčića, (HR-ALZ) Zagreb

Fond: „Križarska organizacija“, kut. 3 i 4.

\section{LITERATURA:}

Artuković, Mato, Nadbiskup Stepinac o sibinjskim žrtvama i mise zadušnice za njih u crkvama Zagrebačke nadbiskupije u veljači i ožujku 1935. godine, Diakovensia, 26., 2018., 583 - 607.

BoвAn, Ljubo, Alojzije Stepinac: nepoznati dnevnik (Stepinčev Dnevnik), Danas, Zagreb, 25. srpnja 1989. - 30. siječnja 1990.

ĆuBELIĆ, Ivan, Biskupske konferencije Jugoslavije i Hrvatski katolički pokret (1919. - 1945.), Zagreb, 1997.

Danica, Hrvatsko književno društvo sv. Ćirila i Metoda, Zagreb, 1972. 27

Encikličko pismo pape Pija XI. „Divini Redemptoris“, o bezbožnom komunizmu, Katolički list, 88. 1937., br. 14. 
JAREB, Mario, Ustaško-domobranski pokret: od nastanka do travnja 1941. godine, 2. izd., Zagreb, 2007.

KRIŠTo, Jure, Hrvatski katolički pokret 1903. - 1945., Glas Koncila, Zagreb, 2004.

Mat ković, Hrvoje, Povijest Jugoslavije, Naklada Pavičić, Zagreb, 1998.

Nagy, Božidar, Dr. Ivan Protulipac u Domovini. Prijenos posmrtnih ostataka dr. Protulipca iz Trsta u Zagreb, u: Ivan Merz, Glasilo Postulature, br. 1-2 (17), Zagreb, 1994.

Perović, Bonifacije, Hrvatski katolički pokret, Zajednica izdanja ranjeni labud, Rim, 1976., 112.

Protulipac, Ivan, Iz prvih dana Križarstva, Nedjelja, br. 77., 1936.

ProtuliPaC, Ivan, U znaku križa, Križ, br. 1., 1930.

Socijalna poslanica Katoličkog Episkopata, Luč, br. 3-4., 1937.

Spomenica, Dr. Ivan Protulipac 1899.-1946., Zagreb, 1996.

Sugar, Peter, Native fascism in the Successor States, 1918-1945. Issue 4 of Twentieth century series. ABC-Clio, 1971.

Švab, Mladen, Milan pl. Šufflay, 120. godišnjica rođenja. Djelo dostojno pozornosti, Vijenac, br. 149/1999.

\section{INTERNET IZVOR:}

Propovijed biskupa Marka Culeja, 26. lipnja 1993., http://krizari.hr/ivanprotulipac-prvi-predsjednik-orlovstva-i-krizarstva-hrvatski-mucenik-18991946/, datum posjeta: 14. srpnja 2020. 


\section{Zdravko MATIĆ \\ Damir STRUČIĆ}

\section{LEGAL PROCEEDINGS AGAINST DR IVAN PROTULIPAC PRESIDENT OF THE CRUSADERS BEFORE THE DISTRICT COURT IN ZAGREB ON JUNE 15, 1938}

\section{SUMMARY}

Following the ban on the Union of Croatian Eagles, Dr Ivan Protulipac and his associates in January 1929 sought a way to establish a new Catholic organization that would have continuity in the Union of Croatian Eagles, which he and Dr Ivan Merz had founded in 1923. Immediately after the founding of the Crusaders in January 1930, Dr Protulipac was subjected to severe pressure from the police authorities of the regime and arrested on January 27, 1930. He was arrested and taken to the police station where the investigation lasted all day-the minutes taken by the police talk about the nature and character of Dr Protulipac's arrest. He was accused of wanting to set up "exercise" societies despite the ban. The procedure was carried out pursuant to Law on the Protection of the State, under which he was arrested and the court proceedings conducted before the Zagreb County Court under the number Kzp. 606-30, dated January 27, 1930, but the case was dismissed, and Dr Protulipac acquitted. In January of the same year, the first issue of the monthly magazine "Križ" was published with an article by Dr Ivan Protulipac outlining the Crusaders' programme, which was entitled "In the sign of the cross" and again the police regime acted promptly. Besides the authors, they also looked for the members of the editorial board and the consortium of the company. Yet criminal proceedings were instituted against him. The same article actually contained all those ideas that Dr Protulipac had been propagating through his twenty years of public activity. It was because of the piece of the same name that he was indicted under the Law on State Protection and in the case before Cr. Court of First Instance dated January 13, 1931, the proceedings were instituted. However, on appeal to Cr. court table, in Zagreb District Court, no. Kps 427/31, the counter-insider and his comrades were acquitted of all charges because the Court could not find anything illegal.

Despite the continued persecution to which he was exposed as President of the Grand Crusaders, Dr Protulipac did not give up his intention to work for the interests of the youth and the Catholic Church. He wanted everything created by Dr Ivan Merz and that he worked on until his death in May 1928, to 
continue living through the generations of Catholic youth and the Crusaders for which he lived.

With his inspirational speech to numerous Catholic youth at the Eucharistic Congress on August 22, 1937, in Bosanski Brod, he again became the subject of an investigation by the regime authorities. He was arrested and charged with the criminal offence referred according to Article 3 of the Law on the Protection of the State of the Kingdom of Yugoslavia. For that offence, the State Prosecutor requested a five-year sentence. However, this time, like all the previous $\mathrm{Dr}$ Protulipac was persistent in proving the truth for which he was fighting. Despite the regime's witnesses testifying against him, the Court found no element for prosecution and conviction and he was again acquitted of all charges.

In all his public appearances, Dr Protulipac was a visionary, a man of faith and a man for the faith and his fellowmen. Even today, his words spoken on the Pope's Day in 1936 are still relevant. "Let us be convinced that the happy future, ours and that of the Croatian people comes first by the grace of the almighty good God. In vain are our efforts and sacrifices if we do not build with God."

Keywords: Ivan Protulipac, PhD, District Court, hearing, Crusaders, trial, judgment. 